\title{
Monochloramine for Remediation of Legionella Only in Domestic Hot Water Systems: An Iron Fist in a Velvet Glove
}

\author{
Stefano Melada ${ }^{1}$, Maria Anna Coniglio $^{2 *}$ \\ ${ }^{1}$ Sanipur US LLC, Conshohocken, PA, USA \\ ${ }^{2}$ Legionella Reference Laboratory, Department of Medical, Surgical Sciences and Advanced Technologies "G.F. \\ Ingrassia", University of Catania, Catania, Italy \\ Email: ${ }^{*}$ ma.coniglio@unict.it
}

Received 19 February 2015; accepted 23 March 2015; published 27 March 2015

Copyright (C) 2015 by authors and Scientific Research Publishing Inc.

This work is licensed under the Creative Commons Attribution International License (CC BY).

http://creativecommons.org/licenses/by/4.0/

(c) (i) Open Access

\begin{abstract}
Monochloramine is a well-known disinfectant for drinking water with several advantages over chlorine and chlorine dioxide. With these two biocides, monochloramine is included in the US-EPA list of disinfectants for drinking water. At the beginning of XXI century, epidemiological studies demonstrated its superior ability to control Legionella in hot water health-care premises. In 2005 a research program started to set up a reliable and effective method to produce monochloramine directly in domestic hot water systems, at the safest concentration and without accumulation of by-products. Results of these researches, which has been carried out with the collaboration of Italian and American Institutions showed that monochloramine can be safely and reliably prepared and that it is the best approach to Legionella remediation in health-care facilities.
\end{abstract}

\section{Keywords}

Monochloramine, Legionella, Legionellosis, Domestic Hot Waters, Prevention

\section{Introduction}

Legionella is an organism of public health interest for its ubiquitous presence in water distribution systems (WDS) and for its ability to cause infection in susceptible humans. Legionella is the causative agent of Legion-

\footnotetext{
${ }^{*}$ Corresponding author.
}

How to cite this paper: Melada, S. and Coniglio, M.A. (2015) Monochloramine for Remediation of Legionella Only in Domestic Hot Water Systems: An Iron Fist in a Velvet Glove. Open Journal of Preventive Medicine, 5, 143-150. 
naire's disease, which appears as a mild respiratory illness—the so-called Pontiac fever-and can develop into an acute life-threatening pneumonia. Elderly adults, smokers and people with weakened immune systems are particularly susceptible.

Worldwide, there have been about 8000 to 18,000 cases of Legionella infection occurring each year. In the United States, between 1980 and 1998, an average of 356 cases was reported to the CDC each year [1]. Between 1995 and 2005, over 32,000 cases of Legionnaires' disease and more than 600 outbreaks were reported to the EWGLI (European Working Group for Legionella Infections) [2].

One of the key issues for controlling the colonization of a WDS is to recommend an effective disinfection method. At present, US-EPA listed disinfectants for drinking water are all based on the $\mathrm{Cl}$ atom [3]. The efficacy of these disinfectants against Legionella vary significantly.

Chlorine is less effective among Cl-based disinfectants and at least 2 - 3 ppm are needed to reach a fair remediation. But under these conditions chlorine is highly corrosive against both metallic and plastic piping. Moreover, its effect is strongly $\mathrm{pH}$-dependent. Chlorine dioxide is a very effective disinfectant and 0.3 - $0.5 \mathrm{mg} / \mathrm{l}$ levels are enough to provide a good remediation but under these conditions chlorine dioxide is very aggressive on all piping materials and as a gas in solution is difficult to maintain residuals in hot water. Finally monochloramine is the most effective Cl-based disinfectant and it is also the most materials respectful. It is effective at concentration of $2-3 \mathrm{mg} / \mathrm{l}$ where it can attain a $0 \%$ colonization within a few weeks of continuous application. Thanks to its stability it is very effective in complex building plumbing system.

Monochloramine is a "chlorine species" that masks its oxidizing power with a softer atom: like an iron fist in a velvet glove. In fact, monochloramine is synthesized from hypochlorous acid and ammonia or an ammonium salt as follows:

$$
\mathrm{NH}_{3}+\mathrm{HOCl} \leftrightarrow \mathrm{NH}_{2} \mathrm{Cl}+\mathrm{H}_{2} \mathrm{O}
$$

During this reaction other chloramines can form (di- and tri-chloramines, respectively $\mathrm{NHCl}_{2}$ and $\mathrm{NCl}_{3}$ ) and $\mathrm{pH}$ plays a key role in the selection of the desired product. Figure 1 shows the effect of $\mathrm{pH}$ on the relative concentration of these three molecules.

Monochloramine is very stable and the predominant species at $\mathrm{pH}$ above 7.2. At this $\mathrm{pH}$ dichloramine and trichloramine (indicated as nitrogen trichloride) cannot form. During chloramination it is important to avoid the formation of di and tri chloramines since they are toxic and odorous molecules. Trichloramine moreover is an explosive liquid but fortunately it cannot be formed in the normal drinking water matrix.

Figure 2 shows the forms in which chlorine can be present at different $\mathrm{pH}$. Hypochlorous acid, the actual biocide, is the predominant form in the $\mathrm{pH}$ range 3 to 7 . At higher $\mathrm{pH}$ it dissociates to hypochlorite ion, which, despite remaining a strong oxidizer, is a weaker biocide.

$$
\mathrm{HOCl} \leftrightarrow \mathrm{OCl}^{-}+\mathrm{H}^{+}
$$

The comparison between Figure 1 and Figure 2 clearly shows that in the $\mathrm{pH}$ range of drinking water the monochloramine is present $100 \%$ in its active form while hypochlorous acid is present in a mixture with hypochlorite ion and that the percent of the active form of free chlorine declines sharply as the $\mathrm{pH}$ increases. This is an important feature showing that free chlorine loses its biocide activity as the $\mathrm{pH}$ increases while it keeps its oxidizing power. This explains the high corrosive potential of free chlorine in drinking water treatment. On the contrary, monochloramine, a weaker oxidant and a weaker biocide, does not show any appreciable difference in its activity in the drinking water $\mathrm{pH}$ range. Moreover, CT values ${ }^{1}$ of monochloramine are higher than that for chlorine (or chlorine dioxide). This is due to the lower oxidation potential of this disinfectant. This is not a drawback, however, because the low reactivity of monochloramine helps it to better penetrate biofilms and kill germs inside. This is why monochloramine is a suitable disinfectant for secondary disinfection where long contact time between the biocide and the bacteria is achieved. This feature is very useful to keep out contamination in dead legs during commissioning and renovation.

Among the antimicrobial agents of relatively most recent application in the disinfection of water, monochloramine seems also to be more effective for decreasing Legionella within the biofilms [4].

As shown on Figure 3, monochloramine and free chlorine have similar diffusion velocities in water at $25^{\circ} \mathrm{C}$,

${ }^{1} \mathrm{CT}$ values are defined as the product of the disinfectant concentration (expressed in mg/L) and the time (in minutes) that potential pathogens in water are in contact with the disinfectant. CT values are assigned for various microorgamisms and are specific for a given temperature and $\mathrm{pH}$ of the water. 


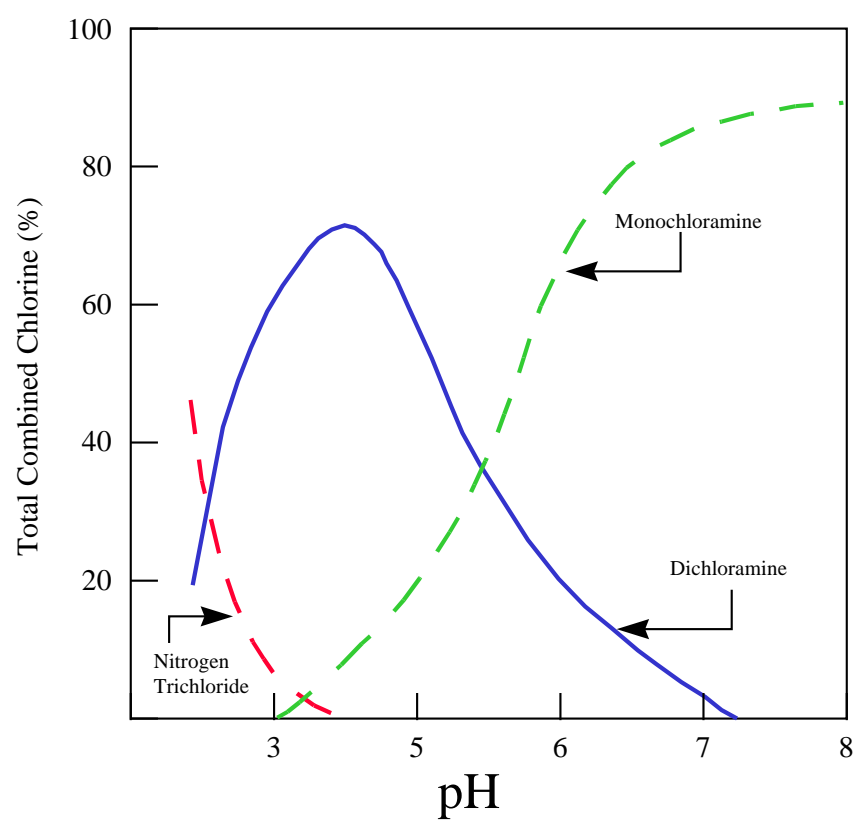

Figure 1. Chloramines species as a function of pH. Source: Palin, A. 1950. "A Study of the Chloro Derivatives of Ammonia." Water and Water Engineering. 54:248-258.

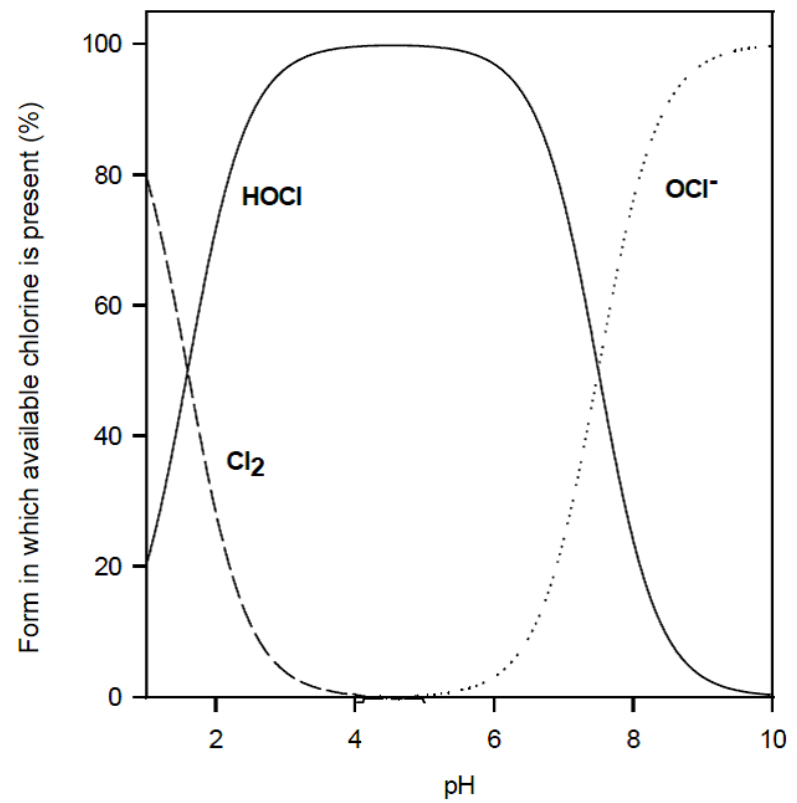

Figure 2. Different free chlorine species present as a function of $\mathrm{pH}$.

so they reach the biofilm the same way. When they reach the biofilm they can react with the biological material (exopolymeric substances, EPS) excreted by microorganisms and be consumed or they can continue the diffusion process. The measured free chlorine microprofiles showed in the picture detail the differences in behavior between free chlorine and monochloramine with biofilm constituents. Whereas chlorine promptly reacts with EPS and is consumed, monochloramine diffuses in the biofilm without being consumed. Free chlorine reacts faster with EPS and the external biofilm layers and it is consumed before it can reach the inner regions of the biofilm where most of the Legionella bacteria lurk. This is the first demonstration of the superior ability of the monochloramine to penetrate biofilms. 


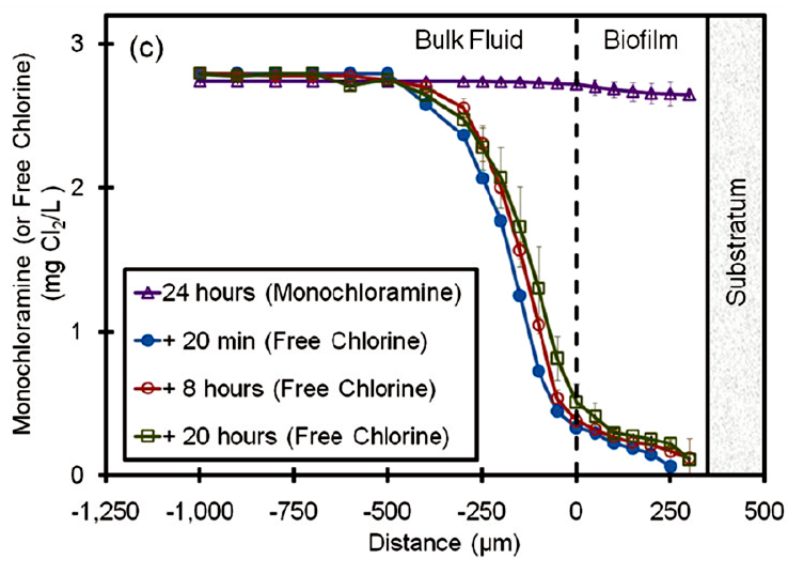

Figure 3. Biofilm penetration of free chlorine and monochloramine determined by microelectrodes. Source: W.H. Lee et al., Env. Sci. Technol. 45 (2011) 1412-1419.

\section{Literature Survey: Comparison of the Three EPA Listed Disinfectants against Legionella}

Table 1 gathers the more significant scientific publications dealing with Legionella remediation with the use of the three EPA listed disinfectants. It is worth noting that 5 of 6 cited papers on monochloramine deal with the use of the disinfectant in the domestic hot water system only, which significantly decreases the risk of DBPs in hospital cold drinking water.

\section{Direct Production of Monochloramine in Domestic Hot Water and Stabilization without Accumulation of by Products}

Nowadays it is possible to produce and dose monochloramine in domestic hot water loops by mixing in a special reactor a chlorine precursor (stabilized hypochlorite) with an ammonium salt as reported in reaction (1).

In a flow-through reactor, the hot water is fed from one side by a recirculation pump, while the reactants are added sequentially. First the ammonium salt, then the stabilized hypochlorite solution. Chemicals addition is made by electromagnetic membrane pumps which are synchronized to reach the best mixing rate in the reaction chamber. The monochloramine is thus produced and exits the reactor within the water flow, which is introduced in the building hot water loop. The only theoretical by-product of reaction (1) is water but, due to the fact that real yield is lower than $100 \%$ you can expect a small amount of free chlorine and free ammonia as the main by-products if the $\mathrm{pH}$ is properly controlled $(\mathrm{pH}>7.2$ in the reaction chamber). Side reactions that can theoretically occur are the formation of di- and tri-chloramine but they are favored at low $\mathrm{pH}$, usually not found in drinking water. The chemical composition of the reagents and the reaction chamber are engineered so that the optimal conditions for the formation of monochloramine are realized.

THM's are produced by the reaction between free chlorine (hypochlorite) and organic substances but the formation of these by-products is minimized by the subsequent reagent addition in the reaction chamber. Feeding ammonium ions before hypochlorite permit the free chlorine to react by the faster reaction (1) so that it is consumed before it can react with the organic substances. The main by-product in cold and domestic hot water loop is the ammonium ion $\left(\mathrm{NH}_{4}^{+}\right)$produced by the decomposition of monochloramine overnight when the water consumption is low or negligible. Thus, reducing any potential hazard to human health. It is possible to minimize the ammonium accumulation in domestic hot water to very low value $(<0.5 \mathrm{ppm})$ by the proper addition of the single reagents on the reactor chamber. Minimization of ammonium ion is not possible in cold water because cold water piping is a flow through system and no water recirculation is normally possible.

\section{New Insights into the Legionella VBNC State}

The recent literature reports the evidence of Legionella entering a viable but not culturable (VBNC) state [21] [23] when monochloramination is applied as the continuous disinfection method. This VBNC state is predomi- 
Table 1. Literature survey of the published paper dealing with Legionella remediation using the three EPA listed disinfectants.

\begin{tabular}{|c|c|c|c|}
\hline Authors & Disinfection method & Concentrations & Results \\
\hline Helms, 1988 [3] & Chlorine & 3 - $5 \mathrm{mg} / \mathrm{l}$ & From $29 \%$ to $<5 \%$ positive sites after 5 years \\
\hline Snyder, $1990[4]$ & Chlorine & $2-5 \mathrm{mg} / \mathrm{l}$ & From $37 \%$ to $7 \%$ positive sites after 17 months \\
\hline Ditommaso, 2006 [5] & Chlorine & $2-3 \mathrm{mg} / \mathrm{l}$ & From $47 \%$ to $6 \%$ positive sites after 5 years \\
\hline Hamilton, 1996 [6] & Chlorine dioxide & $0.5-1 \mathrm{mg} / \mathrm{l}$ & From $28 \%$ to $12 \%$ positive sites after 6 months \\
\hline Srinivasan, 2003 [7] & Chlorine dioxide & $0.8 \mathrm{mg} / \mathrm{l}$ & From $41 \%$ to $4 \%$ positive sites after 17 months \\
\hline Ricci, 2005 [8] & Chlorine dioxide & $0.4-0.5 \mathrm{mg} / \mathrm{l}$ & Persistent colonization of water system \\
\hline Casini, 2008 [9] & Chlorine dioxide & $0.2-0.5 \mathrm{mg} / \mathrm{l}$ & From $67 \%$ to $14 \%$ positive sites after 5 years \\
\hline Hosein, 2005 [10] & Chlorine dioxide & $0.5 \mathrm{mg} / \mathrm{l}$ & From $40 \%$ to $50 \%$ positive sites after 2 years \\
\hline Zhang, 2009 [11] & Chlorine dioxide & $0.5-0.7 \mathrm{mg} / \mathrm{l}$ & From $60 \%$ to $10 \%$ positive sites after 30 months \\
\hline Sidari, 2004 [12] & Chlorine dioxide & $0.3-0.5 \mathrm{mg} / \mathrm{l}$ & From $27 \%$ to $3 \%$ positive sites in 1 month \\
\hline Di Marino, 2007 [13] & Chlorine dioxide & $0.2-0.3 \mathrm{mg} / \mathrm{l}$ & From $60 \%$ to $<5 \%$ in 1 month \\
\hline Marchesi, 2012 [14] & Monochloramine & 2 - $3 \mathrm{mg} / \mathrm{l}$ & From $60 \%$ to $8 \%$ positive sites in 1 month \\
\hline Kandiah, 2012 [15] & Monochloramine & $2-3 \mathrm{mg} / \mathrm{l}$ & From $33 \%$ to $0 \%$ positive sites in 3 weeks \\
\hline Chien, 2012 [16] & Monochloramine & $3-4 \mathrm{mg} / \mathrm{l}$ & Cooling tower, $\mathrm{HPC}<10^{4} \mathrm{cfu} / \mathrm{ml}$ \\
\hline Marchesi, 2013 [17] & Monochloramine & 2 - $3 \mathrm{mg} / \mathrm{l}$ & From $100 \%$ to $9.5 \%$ positive in 1 month \\
\hline Kandiah, 2013 [18] & Monochloramine & $2-4 \mathrm{mg} / \mathrm{l}$ & From $53 \%$ to $0.35 \%$ in 1 year \\
\hline Casini, 2014 [19] & Monochloramine & $2 \mathrm{mg} / \mathrm{L}$ & From $100 \%$ to $0 \%$ positive within 1 month \\
\hline Duda, 2014 [20] & Monochloramine & $2-4 \mathrm{mg} / \mathrm{l}$ & From $53 \%$ to $9 \%$ in one week \\
\hline
\end{tabular}

nant at monochloramine concentration below $1 \mathrm{ppm}$ when resuscitation of Legionella is possible. Between 1 and 2 ppm Legionella can enter the VBNC state but it most cases is no more resuscitable, meaning that the cells are seriously damaged. Above 2 ppm monochloramine can kill most of the Legionella bacteria thus this is the preferred concentration for drinking and hot water disinfection.

Application of chlorine and monochloramine disinfection mixture on cold water at lower residuals seems not to be effective because chlorine itself can cause VBNC state and it does not penetrate biofilm as shown above, whereas monochloramine that penetrate biofilm does not have the right concentration to kill all the bacteria. Moreover, entering the hot water system, chlorine and monochloramine are decomposed and cannot provide sufficient residual disinfectant in the system where Legionella can develop at the highest rate. The right range for Legionella remediation is 2 - 3 ppm, dosed in domestic hot water [4].

\section{Case Histories of the Application of Monochloramine for Remediation of Legionella Only in Domestic Hot Water Systems}

Literature data show that monochloramine, properly applied on the domestic hot water systems and associated to a correct water safety plan, can eradicate Legionella and keep the system safe for several years. The following are examples of published researches which show the efficacy of the application of monochloramine for remediation of Legionella only in domestic hot water systems over several years of application.

\subsection{First Reported Case of Monochloramine-Treated Hospital Building in the USA, UPMC Mercy, Pittsburgh, PA. A 14 Months Survey}

The hospital hot water system was monitored for 14 months following the installation of a monochloramine in- 
jection system. The percent of distal site positivity in the hospital hot water system decreased from an average baseline level of $53 \%$ to an average level of $10 \%$ during the 14 months of system observation following monochloramine installation. A dramatic reduction in observed distal site positivity was observed within one week of monochloramine injection initialization. Monochloramine effectively reduced Legionella colonization within the hospital hot water system throughout the course of the 14 month evaluation. HPC concentrations also fell by approximately $1 \mathrm{log}$. Significant changes in other microbial populations in the hot water system (nitrifying bacteria, mycobacteria, Pseudomonas aeruginosa, Stenotrophomonas maltophilia, and Acinetobacter sp.) were not observed following monochloramine injection. The system was employed in the hot water system only, which significantly decreases the risk of DBPs in hospital cold drinking water [22].

\subsection{Comparison of Monochloramine and Chlorine Dioxide at the University Hospital of Modena, Italy. A 3 Years' Investigation}

In these 3 years' experience, Legionella colonization rapidly decreased after monochloramine treatment and already after 8 months no Legionella contamination was observed. Compared to monochloramine, the effectiveness of chlorine dioxide was lower, with different results according to size and age of the water network. No increase in chlorite levels and no water nitrification occurred in hot water treated with monochloramine, whereas the use of chlorine dioxide was associated with increased levels of both chlorite and chlorate. At distal outlets, monochloramine at concentrations between 2 and $3 \mathrm{mg} / \mathrm{l}$ and chlorine dioxide between 0.50 and $0.70 \mathrm{mg} / \mathrm{l}$ can guarantee a satisfactory control of $L$. pneumophila colonization. In comparison with monochloramine, chlorine dioxide showed a higher frequency of no-flush positive samples, suggesting an increased risk for patients when the tap is turned on [19].

\subsection{Three Years of Monochloramine at the University Hospital of Pisa, Italy}

The Emergency department has been treated with monochloramine since 2010, just before opening. Three years of monitoring showed that the disinfection of domestic hot water with monochloramine has been successful in eradicating Legionella from the building. In December 2010, before the opening of the emergency department, hyperchlorination with $4.00 \mathrm{mg} / \mathrm{L}$ of monochloramine for 4 hours and flushing were performed in order to disinfect the warm water system. Subsequently, the dosage was regulated to obtain a continuous monochloramination to $2 \mathrm{mg} / \mathrm{L}$. Over the course of the investigation, the average observed distal site $\mathrm{NH}_{2} \mathrm{Cl}$ concentration was $1.93 \pm 1.04 \mathrm{mg} / \mathrm{L}$. While at the initial monitoring phase before the start of the monochloramine disinfection, all 6 sites were positive for L. pneumophila sg 1 ST269, with a mean count of $7200 \pm 5300 \mathrm{CFU} / \mathrm{L}$; no samples were positive after treatment [21].

\subsection{Continuous Disinfection by Monochloramine on Domestic Hot Water System of Health-Care Facilities for the Control of Legionella Contamination. A Six Months Experience by the University of Catania, Italy}

A brand new (Nuovo Ospedale di Lentini) and a very old (Ospedale Umberto I, Siracusa) hospitals have been compared in terms of eradication of Legionella with monochloramine on domestic hot water system.

At the beginning of the monitoring program, a systemic colonization of the hospitals' water networks was demonstrated. A $100 \%$ positivity with a mean count ranging from $10^{3}$ to $10^{5} \mathrm{CFU} / \mathrm{L}$ was recorded. After unsuccessful attempts to eradicate Legionella with superheating and flushing, shock hyperchlorination, continuous chlorination and continuous hydrogen peroxide disinfection, the hospitals decided to try monochloramine. Results showed that the efficacy of this technology is the same in the two very different types of domestic hot water systems. In particular, at the "Nuovo Ospedale di Lentini", only 1 week after the start of the new disinfection system, the percentages of positive sample points decreased at $8 \%$, with a mean $L$. pneumophila load lower than $10^{3} \mathrm{CFU} / \mathrm{L}[24]$.

\section{Conclusion}

Monochloramine shows a very high activity against Legionella and long term efficacy even in complex piping and dead legs. Its high compatibility with all kind of pipe material, the easy production settings and the high stability with temperature make it one of the best available technology on the market for the eradication of Legio- 
nella.

\section{Conflict of Interest Statement}

Dr Stefano Melada, responsible for the Research \& Development department of Sanipur Srl and Sanipur US, contributed with a scientific and technical support necessary for the development of the chemical aspects of the issue.

\section{References}

[1] Marston, B.J., Plouffe, J.F., File Jr., T.M., Hackman, B.A., Salstrom, S.J., Lipman, H.B., et al, (1997) Incidence of Community Acquired Pneumonia Requiring Hospitalization-Results of a Population-Based Active Surveillance Study in Ohio. Archives of Internal Medicine, 15, 1709-1718. http://dx.doi.org/10.1001/archinte.1997.00440360129015

[2] Zhan, X.Y., Hu, C.H. and Zhu, Q.Y. (2010) Research Advances of Legionella and Legionnaires’ Disease. Frontiers of Medicine in China, 2, 166-176. http://dx.doi.org/10.1007/s11684-010-0036-3

[3] http://water.epa.gov/drink/contaminants/basicinformation/disinfectants.cfm

[4] Coniglio, M.A., Melada, S. and Yassin, M.H. (2015) Monochlorammine for Controlling Legionella in Biofilms: How Much We Know? Journal of Nature and Science, 1, e44.

[5] Helms, C.M., Massanari, M., Wenzel, R.P., Pfaller, M.A., Moyer, N.P. and Hall, N. (1988) Legionnaires’ Disease Associated With a Hospital Water System. A Five-Year Progress Report on Continuous Hyperchlorination. JAMA, 16, 2423-2427.

[6] Snyder, M.B., Siwicki, M., Wireman, J., Pohlod, D., Grimes, M., Bowman-Riney, S., et al. (1990) Reduction in Legionella pneumophila through Heat Flushing Followed by Continuous Supplemental Chlorination of Hospital Hot Water. Journal of Infectious Disease, 1, 127-132. http://dx.doi.org/10.1093/infdis/162.1.127

[7] Ditommaso, S., Biasin, C., Giacomuzzi, M., Zotti, C.M., Arione, M., Guglielmi, E., et al. (2006) Colonization of a Water System by Legionella Organisms and Nosocomial Legionellosis: A 5-Year Report from a Large Italian Hospital. Infection Control Hospital Epidemiology, 5, 532-535. http://dx.doi.org/10.1086/504454

[8] Hamilton, E., Seal, D.V. and Hay, J. (1996) Comparison of Chlorine and Chlorine Dioxide Disinfection for Control of Legionella in a Hospital Potable Water Supply. Journal of Hospital Infection, 32, 156-160. http://dx.doi.org/10.1016/S0195-6701(96)90058-4

[9] Srinivasan, A., Bova, G., Ross, T., Mackie, K., Paquette, N. Merz, W., et al. (2003) A 17-Month Evaluation of a Chlorine Dioxide Water Treatment System to Control Legionella Species in a Hospital Water Supply. Infection Control Hospital Epidemiology, 24, 575-579. http://dx.doi.org/10.1086/502254

[10] Ricci, M.L., Dell’Eva, I., Scaturro, M., et al. (2005) A Four-Year Experience of a Chlorine Dioxide Treatment for the Control of Legionella in a Hospital Water System. ISTISAN Congressi, 05, 18.

[11] Casini, B., Valentini, P., Baggiani, A., Torracca, F., Frateschi, S., Nelli, L.C., et al. (2008) Molecular Epidemiology of Legionella pneumophila Serogroup 1 Isolates Following Long-Term Chlorine Dioxide Treatment in a University Hospital Water System. Journal of Hospital Infection, 69, 141-147. http://dx.doi.org/10.1016/j.jhin.2008.03.003

[12] Hosein, I.K., Hill, D.W., Tan, T.Y., Butchart, E.G., Wilson, K., Finlay, G., et al. (2005) Point-of-Care Controls for Nosocomial Legionellosis Combined with Chlorine Dioxide Potable Water Decontamination: A Two-Year Survey at a Welsh Teaching Hospital. Journal of Hospital Infection, 61, 100-106. http://dx.doi.org/10.1016/j.jhin.2005.02.008

[13] Zhang, Z., McCann, C., Hanrahan, J., Jencson, A., Joyce, D., Fyffe, S., et al. (2009) Legionella Control by Chlorine Dioxide in Hospital Water Systems. Journal-American Water Works Association, 101, 117-127.

[14] Sidari, F.P., Stout, J.E., VanBriesen, J.M., Bowman, A.M., Grubb, D., Neuner, A., et al. (2004) Keeping Legionella out of Water Systems. Journal-American Water Works Association, 96, 111-119.

[15] Di Marino, O., Valentini, P., Cosentina, R. and Melada, S. (2007) Chlorine Dioxide for Legionellosis Prevention in an Italian Hospital: A Success Story. 22nd Meeting EWGLI, Stockholm, 2-5 June 2007.

[16] Marchesi, I., Cencetti, S., Marchegiano, P., Frezza, G., Borella, P. and Bargellini, A. (2012) Control of Legionella Contamination in a Hospital Water Distribution System by Monochloramine. American Journal of Infection Control, 40, 279-281. http://dx.doi.org/10.1016/j.ajic.2011.03.008

[17] Kandiah, A., Yassin, M.H., Hariri, R., Ferrelli, J., Fabrizio, M., Porter, L., et al. (2012) Control of Legionella Contamination with Monochloramine Disinfection in a Large Urban Hospital Hot Water System. American Journal of Infection Control, 40, e84. http://dx.doi.org/10.1016/j.ajic.2012.04.149

[18] Chien, S.H., Chowdhury, I., Hsieh, M.K., Li, H., Dzombak, D.A. and Vidic, R.D. (2012) Control of Biological Growth 
in Recirculating Cooling Systems Using Treated Secondary Effluent as Makeup Water with Monochloramine. Water Research, 46, 6508-6518. http://dx.doi.org/10.1016/j.watres.2012.09.027

[19] Marchesi, I., Ferranti, G., Bargellini, A., Marchegiano, P., Predieri, G., Stout, J.E. and Borella, P. (2013) Monochloramine and Chlorine Dioxide for Controlling Legionella pneumophila Contamination: Biocide Levels and Disinfection By-Product Formation in Hospital Water Networks. Journal of Water and Health, 11, 738-747. http://dx.doi.org/10.2166/wh.2013.079

[20] Kandiah, A., Yassin, M.H. and Stout, J. (2013) Monochloramine Use for Prevention of Legionella in Hospital Water System. Infectious Disorders-Drug Targets, 13, 184-190. http://dx.doi.org/10.2174/1871526511313030006

[21] Casini, B., Buzzigoli, A., Cristina, M.L., Spagnolo, A.M., Del Giudice, P., Brusaferro, S., et al. (2014) Long-Term Effects of Hospital Water Network Disinfection on Legionella and Other Waterborne Bacteria in an Italian University Hospital. Infection Control and Hospital Epidemiology, 35, 293-299. http://dx.doi.org/10.1086/675280

[22] Duda, S., Kandiah, S., Stout, J.E., Baron, J.L., Yassin, M., Fabrizio, M., et al. (2014) Evaluation of a New Monochloramine Generation System for Controlling Legionella in Building Hot Water Systems. Infection Control and Hospital Epidemiology, 35, 1356-1363. http://dx.doi.org/10.1086/678418

[23] Alleron, L., Khemiri, A., Koubar, M., Lacombe, C., Coquet, L., Cosette, P., et al. (2013) VBNC Legionella pneumophila Cells Are Still Able to Produce Virulence Proteins. Water Research, 47, 6606-6617. http://dx.doi.org/10.1016/j.watres.2013.08.032

[24] Coniglio, M.A., Andolfi, N., Faro, G., Pellegrino, M.B., Sgalambro, A., D’Aquila, G., et al. (2014) Monochloramine for the Control of Legionella Contamination of Domestic Hot Water Systems of Health-Care Facilities. A Six Months Experience from Sicily (Italy). 2nd ESGLI Congress, Barcelona, 17-19 September 2014. 